\title{
The Relationship Between Enterprise Innovation Performance and Government Subsidies Based on Signaling Model
}

\author{
Anhua Yang \\ Business School of Sichuan University \\ Chengdu, China
}

\author{
Tongyu Wang \\ Business School of Sichuan University \\ Chengdu, China
}

\begin{abstract}
This paper takes a sample of China's GEM listed companies from 2015 to 2017 to study the relationship between government subsidies and enterprise innovation performance. Furthermore, we examine the effect of government subsidies on enterprise innovation performance from the perspectives of regions, ownership, and industry. The results show that there is a positive correlation between government subsidies and enterprise innovation performance, and this promotion is more pronounced in developed regions, strategic emerging industries and non-state-owned enterprises. This study has important value for understanding government subsidies in promoting independent innovation and solving financing constraints of enterprises.
\end{abstract}

Keywords—government subsidies; innovation performance; signaling model

\section{INTRODUCTION}

As China's economic growth mode shifted from extensive to intensive, enterprises play an important role in promoting national technological progress as main body of innovation. In the process of economic transition, government subsidies, as a policy tool, can be used by the government to achieve various policy goals through the form of economic compensation for enterprises and play an increasingly important role in guiding industrial upgrading. And it gradually become an important impetus of China's economic transformation. However, in contrast to this, there is an enormous controversy in the academia about the relationship between government subsidies and enterprise technological innovation. The view that the government subsidies have a 'positive effect' suggests that government subsidies will help offset the market failures in the process of innovation, promote the level of enterprise innovation, and accelerate enterprise technological innovation activities. The view that the government subsidies have 'negative effects' suggests that the government's selective grant policy has a crowding-out effect on the company's innovation investment, which reduces the incentive effect and the false signals released by the company are likely to reach the purpose of the deception policy makers (Rodrik D.2004). It can be seen that the existing literature has not drawn a unanimous conclusion on the relationship between government subsidies and enterprise technological innovation. There is a huge controversy and it remains an important issue to be tested, and it is necessary to further exploring.

This study examines the relationship between government subsidies and enterprise innovation performance based on data from companies listed on GEM. Our research may enrich the existing literature in the following three aspects: (1) This paper enriches and perfects the theoretical research on government subsidies and enterprise innovation performance. Based on the information transition theory, this paper theoretically illustrates the process of government subsidies affecting enterprise innovation performance, which enriches and deepens the understanding of the enterprise innovation process; (2) From the perspective of the existing literature, most research of relationship between government subsidies and corporate $\mathrm{R} \& \mathrm{D}$ investment focused on the impact of corporate R\&D investment from government subsidies. This study analyzes the effect of government subsidies from the perspective of enterprise innovation performance. At the same time, we select the sample of GEM listed companies with relatively large government subsidies as a sample to provide strong empirical evidence for the research in this field; (3) Based on the corporate characteristics, this study found that the impact of government subsidies on enterprise innovation performance has significant regional, ownership and industry differences. These findings provide a unique perspective on understanding the different effect on government subsidies in the field of corporate technological innovation.

The structure of this paper is as follows: The second section is the literature review and research hypothesis. The third section conducts an empirical test of this study. The fourth section is the conclusion.

\section{LITERATURE REVIEW AND RESEARCH HYPOTHESIS}

\section{A. The Effect of Government Subsidies on Enterprise Innovation Performance}

Government subsidies are an important component of fiscal expenditure. It is the free capital transfer provided by the government that directly or indirectly to the microeconomic entities according to specific purposes for a certain period of time (Kong Dongmin, 2013). There are two major ways for the government to provide technical 
subsidies to enterprises. One is to provide funds through budgetary arrangements to enterprises, known as direct subsidies. And the other is to subsidize enterprises through preferential policies such as tax incentives and government procurement, which is called indirect subsidies. The specific contents of government subsidies include VAT return, financial subsidies, fiscal consolidation, return of new products, tax incentives and innovation incentives and other government subsidy programs (Wang Hongjian, 2014). This study is based on direct subsidies of enterprises. And we use the 'government subsidies' disclosed by listed companies to represent the amount of government subsidies received by listed companies in the current period and uses the total revenue at the end of the period for standardization to facilitate comparison.

Government subsidies are actually an administrative method commonly used by various governments to guide corporate behavior. The influence and consequences of this guiding behavior have a very close relationship with the health of the entire country. Therefore, many scholars in academia have studied this. During the study, a large number of theories have been generated. The generally accepted theories mainly include industrial organization, strategic management, and information transition theory. Industrial organization scholars believe that the reason why the government uses subsidy policies is to solve the problem of technical innovation market failure. Hewitt-Dundas and Roper (2010) summarized three possible "superimposed effects" of government subsidies: The first is the 'universal' superposition effect, that is, with government funding, more companies are committed to product innovation. The second is the 'improved' superposition effect, which is, the quality of the innovation and the contribution to the society have increased in the process of gradual innovation; the third is the 'innovative' superposition effect, which is, the proportion and quality of breakthrough innovations made by companies have been improved. Hewitt-Dundas and Roper (2010) believe that these three effects occur because government subsidies can reduce the cost of enterprise innovation or reduce the risk of innovation and commercialization of enterprises, thus positively influencing the innovation decisions of enterprises. Strategic management scholars proceed from the basic theory of resources and believe that government subsidies have at least three functions for enterprises: First, government subsidies can be regarded as a specific redundant resource; secondly, government subsidies can be considered as an institutional legality; thirdly, to a certain extent, government subsidies will create pressure for innovation in enterprises, forcing companies to further increase their investment in technology research and expand their innovation results.

Based on the information transition theory, this paper studies the role of government subsidies in the corporate innovation process and establishes a signaling model as shown in "Fig. 1". Signaling refers to the use of certain means to send specific information to the hands of specific information demanders, manifested as information reception, information feedback, and economic benefits. The government direct subsidies to enterprises can reduce the capital constraints of enterprises, so that enterprises have enough funds to engage in innovation activities. This 'Government Subsidies' signal is accepted by companies and could promote enterprises to increase investment in innovation, and has a significant role in promoting the innovation investment of enterprises (Xie Weimin et al., 2009); This 'Government Subsidies' signal is received by external investors, especially for banks and venture investors, they can effectively solve the problem of information asymmetry with companies, increase corporate debt financing and equity financing, solve financing difficulties caused by adverse selection, further achieve independent innovation of enterprises, and finally improve enterprise innovation performance. At the same time, the improvement of enterprise innovation performance also has a negative effect on innovation. The improvement of innovation performance has a positive impact on the growth of enterprises, and it is more helpful for enterprises to increase innovation investment, solve financing constraints, and promote the further increase of enterprise innovation performance. Based on the above theoretical analysis, this paper proposes Hypothesis 1:

Hypothesis 1: There is a positive relationship between government subsidies and enterprise innovation performance.

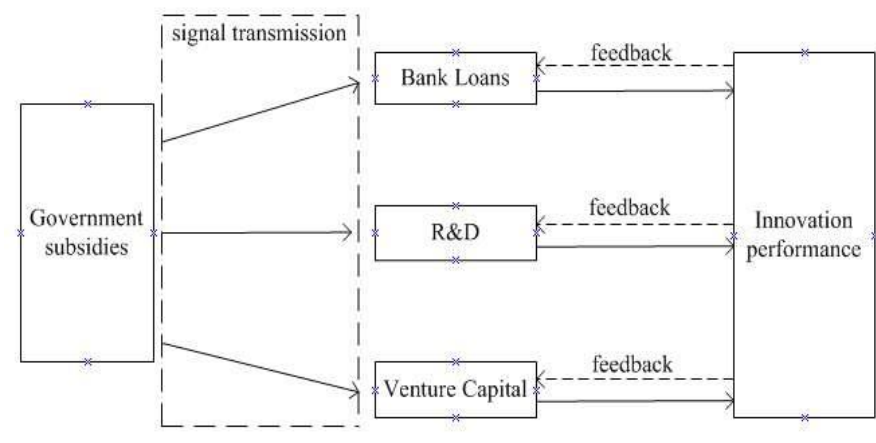

Fig. 1. Signal transfer model.

\section{B. The Effect of Government Subsidies on Enterprise Innovation Performance: the Role of Industry Differences}

Strategic emerging industries are based on major technological breakthroughs and major development needs and have a major role in stimulating the overall economic development and long-term development. They are usually enterprises that knowledge-intensive technologies, low material resources consumption, large growth potential, and comprehensive benefits. The core of strategic emerging industries is technological innovation. As technologyintensive industries, it is characterized by a high degree of technology in the two elements of labor and capital input and reflects a large number of $R \& D$ investment activities in its products. On the other hand, strategic emerging industries are capital-intensive industries with large investment, slow capital turnover, and a stronger demand for funds. Therefore, government subsidies for strategic emerging industries can play a more significant role in corporate innovation activities and can promote the improvement of enterprise innovation performance. According to the characteristics of strategic 
emerging industries, based on China's national conditions and industrial base, we focus on cultivating and developing energy conservation and environmental protection, a new generation of information technology, biology, high-end equipment manufacturing, new energy, new materials, new energy vehicles and other industries at this stage. Therefore, this paper classifies GEM listed companies into two categories: strategic emerging industries and non-strategic emerging industries. We study the effect of industry differences on the impact of government subsidies on enterprise innovation performance. Based on the above theoretical analysis, this paper proposes Hypothesis 2:

Hypothesis 2: The role of government subsidies in promoting enterprise innovation performance is even more pronounced in emerging strategic industries.

\section{The Effect of Government Subsidies on Enterprise Innovation Performance: the Role of Ownership Differences}

First of all, state-owned enterprises rely on the natural connection between the enterprise and the government, which can usually obtain more policy support from the government. Therefore, the state-owned enterprises and nonstate-owned enterprises have obvious differences in their innovation and development. Specifically, compared with state-owned enterprises, non-state-owned enterprises are often faced with financial constraints in terms of financing and cannot obtain effective innovation support, which leads to be more eager and sensitive to government support. For non-state-owned enterprises, government subsidies can alleviate to some extent the restraining effect of financing constraints on corporate innovation, promote enterprise technological innovation activities through fiscal transfer payments, and reduce the investment risks of enterprises. By this way, government subsidies could effectively improve the enterprise innovation performance of non-state-owned enterprises.

Secondly, compared with non-state-owned enterprises, state-owned enterprises have low operating efficiency. And there are many problems with internal systems and management. This has been repeatedly confirmed by research on ownership structure and corporate performance. Wang Yebin et al. (2012) found that government investment could significantly promote the innovation activities of hightech industries, but the impact of government investment on technological innovation is different because of different ownership structures. When the proportion of state-owned economy is higher, the impact on technological innovation is smaller. Based on the above theoretical analysis, this paper proposes Hypothesis 3:

TABLE I. BASIC CHARACTERISTICS OF SAMPLE COMPANIES

\begin{tabular}{|c|c|c|c|c|c|c|c|}
\hline Feature & Classification & Amount & $\begin{array}{c}\text { Accounting } \\
(\%)\end{array}$ & Feature & Classification & Amount & $\begin{array}{c}\text { Accounting } \\
(\%)\end{array}$ \\
\hline \multirow{3}{*}{$\begin{array}{ll}\text { Number } & \text { of } \\
\text { patents (a) } & \end{array}$} & 20 & 416 & 74.15 & \multirow[t]{3}{*}{$\mathrm{R} \& \mathrm{D}$ ratio $(\%)$} & $1 \%$ & 9 & 1.61 \\
\hline & $20-100$ & 130 & 23.17 & & $1 \%-20 \%$ & 536 & 95.54 \\
\hline & 100 & 15 & 2.68 & & $20 \%$ & 16 & 2.85 \\
\hline \multirow{3}{*}{$\begin{array}{l}\text { Operating income } \\
\text { (ten thousand } \\
\text { yuan) }\end{array}$} & 70000 & 324 & 57.75 & \multirow{3}{*}{$\begin{array}{l}\text { Number of } \\
\text { employees } \\
\text { (person) }\end{array}$} & 800 & 257 & 45.81 \\
\hline & $70000-400000$ & 220 & 39.22 & & $800-2000$ & 206 & 36.72 \\
\hline & 400000 & 17 & 3.03 & & 2000 & 98 & 17.47 \\
\hline \multirow[t]{2}{*}{ industry } & $\begin{array}{l}\text { Strategic Emerging } \\
\text { Industries }\end{array}$ & 243 & 43.32 & \multirow[t]{2}{*}{ Ownership } & $\begin{array}{l}\text { State-owned } \\
\text { holding company }\end{array}$ & 43 & 76.65 \\
\hline & $\begin{array}{l}\text { Non-strategic } \\
\text { emerging industries }\end{array}$ & 318 & 56.68 & & $\begin{array}{l}\text { Non-state-owned } \\
\text { holding company }\end{array}$ & 518 & 92.34 \\
\hline
\end{tabular}

Hypothesis 3: The role of government subsidies in promoting enterprise innovation performance is more pronounced in non-state-owned enterprises.

\section{The Effect of Government Subsidies on Enterprise Innovation Performance: the Role of Regional Disparities}

When considering the regional differences, companies in more economically developed regions are considered to be more competitive than those in other regions. They have higher levels of openness, higher levels of management, and better internal governance. For science and improvement, it can make full use of resources to improve the efficiency of the company's innovation. Secondly, enterprises in economically developed regions have a high level of development and pay more attention to their innovation activities. Therefore, for enterprises in economically developed regions, investment in $R \& D$ can promote the higher growth of innovation performance. When government subsidies are used as R\&D investment, they can also take more enterprise innovation performance than those in economically underdeveloped regions. Based on the above theoretical analysis, this paper proposes hypothesis 4:

Hypothesis 4: The role of government subsidies in promoting enterprise innovation performance is more pronounced in developed regions.

\section{EMPIRICAL ANALYSIS}

\section{A. Sample Selection and Data Sources}

This article mainly studies the relationship between government subsidies and corporate innovation performance. For this reason, this article selected companies listed on the GEM from 2015 to 2017 as research samples. The reason for choosing a GEM listed company is that most of the companies listed on the GEM are engaged in high-tech business, have a high growth, have a greater need for funds, and pay more attention to the innovation and development of 
the company. The patent data come from the State Patent Office and the State Intellectual Property Office online database. Government subsidies, research and development costs, and corporate financial indicators come from the wind information database. After removing the missing values, we finally obtained 561 corporate observation samples.

"Table I" lists the selected sample of corporate patents, R\&D ratios, operating income, number of employees, industry, and ownership. From the perspective of the number of patents, enterprises with less than 20 patent outputs in the year accounted for $74.15 \%$ of the total number of samples, and those with more than 20 patent outputs in the year accounted for $25.85 \%$ of the total number of samples, reflecting the comparison of patent output of Chinese enterprises in general. From the perspective of $R \& D$ investment, companies with R\&D investment ratios between $1 \%$ and $20 \%$ accounted for $95.54 \%$ of the total sample. This reflects that Chinese companies' R\&D investment levels have been greatly improved compared to previous years, but are still at a relatively low level. In terms of operating income and number of employees, the size of the selected sample is more evenly distributed.

\section{B. Research Variable Definition and Model Establishment}

This article uses government subsidies as a percentage of operating revenue to measure the intensity of government subsidies. Technological innovation generally refers to the innovation activities that are based on the principle of acquiring independent intellectual property to master core technologies. Patent, as the main output and result representation of the enterprise's innovation activities, is a concentrated expression of independent intellectual property rights of enterprises. The enterprise innovation performance is used as the explanatory variable of this paper, and it is measured by the number of enterprise patent applications.

In terms of control variables, this article controls $R \& D$ investment, company size, debt level, profitability, age, and capital intensity. The definitions of specific variables are shown in "Table II". $\varepsilon$ is a random disturbance item. In order to avoid the influence of outliers on the model analysis, Winsorize was performed on the variables at the level of $1 \%$ and $99 \%$. The models are as follows:

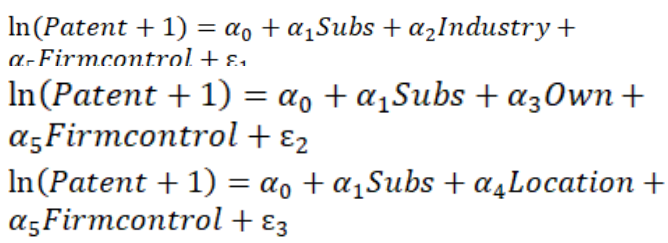

TABLE II. VARIABLE DEFINITIONS

\begin{tabular}{|c|c|c|}
\hline & $\begin{array}{l}\text { Variable } \\
\text { name }\end{array}$ & Variable description \\
\hline $\begin{array}{l}\text { Explained } \\
\text { variable }\end{array}$ & Performance & Enterprise innovation performance, $\ln$ (the total number of patent applications in the next year +1 ) \\
\hline \multirow{4}{*}{$\begin{array}{l}\text { Explanatory } \\
\text { variables }\end{array}$} & Subs & Government subsidies, government grants / main business income \\
\hline & Industry & $\begin{array}{l}\text { The industry uses dummy variables to indicate that strategic emerging industries are represented by } 1 \text { and non- } \\
\text { strategic emerging industries are represented by } 0 \text {. }\end{array}$ \\
\hline & Own & $\begin{array}{l}\text { Ownership is represented by dummy variables, state-controlled enterprises are denoted by } 1 \text {, and non-state- } \\
\text { controlled enterprises are represented by } 0 \text {. }\end{array}$ \\
\hline & Location & $\begin{array}{l}\text { Regions are represented by dummy variables, which are denoted by } 1 \text { in economically developed regions and } 0 \text { by } \\
\text { non-economically developed regions. }\end{array}$ \\
\hline \multirow{6}{*}{$\begin{array}{l}\text { Control } \\
\text { variable }\end{array}$} & R\&D & $\mathrm{R} \& \mathrm{D}$ investment, $\mathrm{R} \& \mathrm{D}$ expenses/main business income \\
\hline & Size & Size of company, total assets / total number of employees \\
\hline & Lev & Liabilities, liabilities/total assets \\
\hline & Roa & Profit level, profit/total assets \\
\hline & Age & Age, years of business establishment \\
\hline & $\mathrm{Ki}$ & Capital Intensity, Gross Fixed Assets / Total Employees \\
\hline
\end{tabular}

\section{Empirical Results}

"Table III" shows the impact of government subsidies on corporate innovation performance, and the extent to which government subsidies affect corporate innovation performance in the context of industry, ownership, and regional differences. Observing the first column, the regression coefficient of government subsidies for corporate innovation performance is 1.088 , which is significantly greater than 0 at the $5 \%$ level. This shows that government subsidies promote corporate innovation performance. The empirical results support Hypothesis 1. Observed in the second column, the regression coefficient of government subsidies for corporate innovation performance is 1.182 , which is significantly greater than 0 at the $5 \%$ level, and is greater than the coefficient of the first column of government subsidies, and the coefficient of the industrial variables is 0.686 , which is at the level of $5 \%$. Significantly greater than 0 . This shows that government subsidies play a more significant role in the innovation performance of strategic emerging industries. The empirical results support Hypothesis 2. Observed in column 3, the regression coefficient of government subsidies for corporate innovation performance is 1.173 , which is significantly greater than 0 at the $5 \%$ level, and is larger than the coefficient of the first column of government subsidies, and the coefficient of ownership variation is -0.871 , which is $5 \%$. Significantly greater than 0 in level. This shows that government subsidies play a more significant role in the innovation performance of non-state-owned companies, and the empirical results 
support Hypothesis 3. Observed in column 4, the regression coefficient of government subsidies for corporate innovation performance is 1.099 , which is significantly greater than 0 at the $5 \%$ level, and is greater than the coefficient of the first column of government subsidies, and the coefficient of regional variables is 0.165 , at the level of $5 \%$. Significantly greater than 0 . This shows that government subsidies have a more significant effect on the innovation performance of enterprises in economically developed regions. The empirical results support hypothesis 4 .

TABLE III. REGRESSION RESULTS

\begin{tabular}{|c|l|l|l|l|}
\hline & & Model (1) & \multicolumn{1}{|c|}{ Model (2) } & Model (3) \\
\hline Subs & $1.088^{* *}$ & $1.182^{* *}$ & $1.173^{* *}$ & $1.099^{* *}$ \\
& $(0.037)$ & $(0.040)$ & $(0.021)$ & $(033)$ \\
\hline Industry & & $0.686^{* *}$ & & \\
& & $(0.049)$ & & \\
\hline Own & & & $-0.871^{* *}$ & \\
& & & $(0.034)$ & \\
\hline Location & & & & $0.165^{*}$ \\
& & & & $(0.069)$ \\
\hline R\&D & $1.052^{* *}$ & $1.176^{* *}$ & $0.989^{* *}$ & $1.039^{* *}$ \\
& $(0.029)$ & $(0.024)$ & $(0.044)$ & $(0.042)$ \\
\hline Size & 0.246 & 0.205 & 0.375 & 0.249 \\
& $(0.277)$ & $(0.305)$ & $(0.205)$ & $(0.344)$ \\
\hline Lev & $-0.741^{* * *}$ & $-0.764^{* * *}$ & $-0.743^{* * *}$ & $-0.709^{* * *}$ \\
(negative) & $(0.000)$ & $(0.000)$ & $(0.000)$ & $(0.000)$ \\
\hline Roa & $-1.402^{*}$ & $-1.438^{*}$ & -1.398 & -1.398 \\
(negative) & $(0.099)$ & $(0.087)$ & $(0.163)$ & $(0.163)$ \\
\hline Age & -1.395 & -1.363 & -1.396 & -1.393 \\
& $(0.164)$ & $(0.174)$ & $(0.163)$ & $(0.164)$ \\
\hline Ki & 0.700 & $0.771^{*}$ & $0.733^{*}$ & $0.681^{*}$ \\
& $(0.90)$ & $(0.077)$ & $(0.084)$ & $(0.093)$ \\
\hline Constant & $11.134^{* * *}$ & $11.147^{* * *}$ & $11.157^{* * *}$ & $10.586^{* * *}$ \\
term & $(0.000)$ & $(0.000)$ & $(0.000)$ & $(0.000)$ \\
\hline $\mathbf{R}^{2}$ & 0.52 & 0.53 & 0.53 & 0.52 \\
\hline $\mathbf{N}$ & 561 & 561 & 561 & 561 \\
\hline
\end{tabular}

a. Note: $* * *, * *, *$ are significant at the $1 \%, 5 \%$, and $10 \%$ levels, respectively, and the standard error is in parentheses.

\section{CONCLUSION}

This paper takes China's GEM listed companies as a sample, studies the relationship between government subsidies and corporate innovation performance, and examines the effects of government subsidies on corporate innovation performance from three perspectives: regional, ownership, and industry. The results show that: (1) There is a positive relationship between government subsidies and corporate innovation performance; (2) Government subsidies have a more pronounced effect on the innovative performance of strategic emerging industries; (3) Government subsidies for non-state-controlled enterprises The role of innovation performance is more pronounced; (4) Government subsidies have a more pronounced effect on the innovation performance of enterprises in economically developed regions. This study has important value for understanding government subsidies in promoting independent innovation and solving corporate financing constraints.

\section{REFERENCES}

[1] Rodrik D.Industrial policy for the 21 st century [R]. WorkingPaper, 2004.

[2] Kong Dongmin,Liu Shasha,Wang Yanan. Market competition, property rights and government subsidy[J]. Journal of Economic Research, 2013(2):55-67.

[3] Wang Hongjian,Li Qingyuan,Xing Fei. Financial crisis, government subsidy and surplus manipulation--empirical evidence from Chinese listed companies[J]. Management World, 2014(7):157-167.

[4] Hewitt-Dundas N, Roper S. Output additionality of public support for innovation: Evidence for Irish manu-facturing plants [J]. European Planning Studies, 2009, 50(1): 107 - 122. R. Nicole, "Title of paper with only first word capitalized," J. Name Stand. Abbrev., in press.

[5] Meng Huanhuan. Research on the influence of government subsidy and financial development on enterprise innovation[D]. Zhejiang University of Finance \& Economics, 2016.

[6] Fuliping, Li Xiaojing. Analysis of the signal transmission effect of government subsidy in the process of enterprise innovation--based on the panel data of the listed companies of strategic emerging Industries Jane [J]. Systems Engineering, 2014 (11): 50-58.

[7] Wang Yi-hui. Government subsidy, research and development investment and enterprise innovation performance--based on ownership, enterprise experience and regional difference [J]. Exploration of economic problems, 2013 (7): 138-143.

[8] Wu Jianfeng, Yang Zhenning. Government subsidy, separation of two rights and technological innovation of enterprises $[\mathrm{J}]$. Scientific research Management, 2014, 35 (12). 